Kastamonu Eğitim Dergisi
$\begin{aligned} & \text { Kastamonu Education Journal } \\ & \text { Mart 2020 Cilt:28 Sayı:2 }\end{aligned}$
kefdergi.kastamonu.edu.tr

\title{
Matematik Öğretiminde Negatif Bilgiye Dayalı Uzman Sistem Değerlendirme Yazılımı Kullanımının Akademik Başarıya Etkisi
}

\section{The Effect Of Using Expert System Evaluation Software Based on Nega-tive Knowledge to Academic Success in Math Education}

\author{
Ümit DEMiR ${ }^{1}$, Gülden DEMiR²
}

Öz

Bu araştırma, uzman sistem değerlendirme yazılımı kullanımının matematik eğitiminde değerlendirme sürecinde hataların belirlenerek düzeltilmesinin öğrenci akademik başarısına etkisini belirlemek amacıyla gerçekleştirilmiştir. Bu çalışmada, ön test-son test kontrol gruplu deneysel desen kullanılmıştır. Deney grubu öğrencileri değerlendirme yazılımı kullanmış, ancak kontrol grubu öğrencileri kullanmamıştır. Çalışmanın örneklemi Çanakkale / Türkiye'de bulunan bir ortaokulda öğrenimlerine devam etmekte olan 71 7. sınıf öğrencisinden oluşmaktadır. Araştırmada araştırmacılar tarafından geliştirilen öğrenme hatalarının düzeltilmesine yönelik geliştirilmiş olan eğitimsel değerlendirme yazılımı kullanıımıştır. 4 haftalık deneysel işlemin ardından beşinci haftanın sonunda, öğrencilerin akademik başarıları sontestle belirlenmiştir. Araştırma sonucunda; deney grubunun (uzman sistem değerlendirme yazılımı kullanan) ön testsontest akademik başarı puanları arasında anlamlı bir fark [t(34)=-7.85, $\mathrm{p}<.05]$ bulunmuştur. Ayrıca kontrol ve deney gruplarının öntest puanları arasında anlamlı bir farklılık yok iken $[t(69)=-0.82, p>.05]$ sontest puanlarında anlamlı fark $[t(69)=-2.07, p<.05]$ bulunmuştur.

Anahtar Kelimeler: Uzman sistem, zeki öğretim sistemi, negatif bilgi

\section{Abstract}

This research was conducted to determine the effects of the using Expert System Evaluation (ESE) software in the assessment and evaluation processes for determining and correcting the wrong answers of the students in math education. Experimental design with the pretest-posttest control group was used in this study. ESE software was used for the Experimental Group but it was not used for the Control Group. The study group consists of 71 7th grade students who are studying at a secondary school located in Çanakkale/Turkey. In the study, educational evaluation software based on correcting the correcting misconceptions developed by the researchers was used. At the end of the fifth week following the 4-week experimental procedure, the academic achievement of the students was determined by the post-test. As a result of this research; it was found to be a significant difference $[t(34)=-7.85, p<.05]$ between the pretest-posttest academic achievement scores of the experimental group (using expert system evaluation software). In addi-tion, there was no significant difference $[t(69)=-0.82, p>.05]$ between the pretest scores of the experimental and control groups. There was a significant difference $[t(69)=-2.07, p<.05]$ in posttest scores.

Keywords: Expert system, intelligent tutoring system, negative knowledge 


\section{Extended Abstract}

Introduction: Intelligent Tutoring System (ITS) is one of the most used approaches in the field of education of expert systems, one of the applications of artificial intelligence technology. Expert System is defined as a computer program that is provided by one or more of the human experts in this area covering a very wide range of information related to that field in a given field and acts like these experts in problem-solving (Allahverdi, 2002; Körez, 2009). The modules used by the structure of the expert system, the student can provide personalized feedback and problems. Expert system-based instructional software is systems based on creating a user or student model by recording the progress and user preferences of the students during the information acquisition process (Önder, 2003). These systems organize lear-ning and teaching processes by guiding students according to their personal characteristics. ITS; whether the student answers are wrong, whether the students answer the questions, whether they are in the right order, and so on. compa-res situations and directs students according to their individual needs in the teaching and learning process. When they are used instead of traditional teaching methods, the students give shorter and more effective learning opportunities (Hotomaroğlu, 2002). One of the advantages provided by ITS is the ability to provide urgent explanations and feed-back to the students when they need (Kaya and Korkmaz, 2007). Because learning mistakes can offer many opportunities for teachers to correct their learning and reconfigure the teaching process.

Although evaluation is considered the same as tests, evaluation is a process involving more than just testing and recording results (Kargın, 2007). This process involves a careful analysis of the information provided by different tools and techniques, including tests, and the results obtained should include functional and appropriate decisions. Deciding which tool and technique are appropriate will vary depending on the purpose of the evaluation (Salvia and Ysseldyke, 2001; Turnbull et al., 2007). The true and wrong answers of the students are described by the concepts of positive and negative knowledge in the evaluation process (Gartmeier et al., 2008).

Research Method: The research was carried out with an experimental research model. The gender, level of computer literacy were the independent variables of the research. The academic achievement of the students was the dependency variable of the research. The practice was carried out with 71 th grade students who continue their education at a secondary school in Çanakkale/Turkey. The practice was carried out with students showing a similar success in the 7th-grade math lessons of the school

Findings: In the findings obtained in the research; it was seen that there was a significant difference in posttest scores of students using expert system evaluation software compared to pretest scores. Also, it shows a significant difference according to the score of the control group in the posttest scores of the experimental group using the software. As a result, the use of expert system evaluation software has been found to increase the academic achievement of stu-dents. This result obtained in the research confirms the results of the application indicating that the application of an intelligent tutoring system based expert system evaluation software is successful in correcting student conceptual misconceptions (Ayas, Köse \& Taş, 2003: 106-112; Browning \& Lehmen, 1988: 741-761; Büyükkasap et al., 1998: 59-66; Kaya \& Korkmaz, 2007; Mitrovic et al., 2013; Woerner, 1980). It is important that the teaching material address multiple senses in maintaining the permanence of the learners. In addition, it is very important to develop and use teaching activities that can motivate students' visual and intellectual structures while explaining abstract and difficult concepts (Ertepınar ve diğer, 1998).

Conclusion: It is considered that more effective and instructive teaching software can be developed by including measurement evaluation systems which enable students to correct mistakes in ITS applications. Because the use of negative knowledge, which is revealed as a result of mistakes, may allow different opportunities for teaching. These opportuni-ties can be summarized as providing an individual's depth of understanding, enhancing the ability to cope with comp-lex situations-problem solving skills, specializing in knowledge, and supporting learning at higher levels (Akpınar and Aydoğan, 2010; Gartmeier et al., 2008). Negative knowledge should also be included as a supplement to the positive knowledge in this education. However, when teaching mistakes are used as a learning path, care should be taken to ensure that mistakes are made to prevent further mistakes (Heinze, 2005).

As a result, expert systems have good qualifications to provide student-centered learning environments. In software designs, we generally forget to give importance to the evaluation process. Subject description part of the software is not enough alone. So using negative knowledge can also support feedback and evaluation parts. By using these tools learning may be more personal and comfortable for learners. 


\section{Giriş}

Elektronik öğrenme, bilgi ve iletişim teknolojilerinde meydana gelen ilerlemenin sonucu oluşan öğretim tasarımıdır. Bu tasarımın, öğretim içeriklerinin işitsel-görsel farklı tasarımlarla zenginleştirilebilmesi ve kullanı-cılara içeriklerinine istenilen yer, istenilen zamanda az maliyetle, kısa sürede ulaştırılabilmesi gibi avantajları bulunmaktadır (Arıcı ve Karacı, 2013). Öğretim sürecinde bilgisayar kullanmanın amacı; öğrenme sürecine yardımcı olmasıdır. Bu süreçte öğretim teknolojileri hızlı bir şekilde gelişim gösterek daha etkin öğretim yön-tem ve tekniklerinin çıkmasını sağlamaktadır. Bu öğretim yöntemlerinden birisi de zeki öğretim sistemi (ZÖS)'dir.

ZÖS; kime, neyi, nasıl öğreteceğini bilen kişiye göre uyarlanabilir olan bilgisayar tabanlı bir yazılım siste-midir (Karacı, 2014; Kaya ve Korkmaz, 2007; Toussas, Chrysafiadi ve Viryou, 2019). ZÖS, her öğrencinin kendi kendine bireysel eğitim ve öğrenme imkanı sunması, zeki yönlendirme ve destek sağlaması, mekan ve zamandan bağımsız bir şekilde çalışma imkanı sağlamasından dolayı eğitim alanındaki uygulamaları giderek artmaktadır (Dağ ve Erkan, 2004; Karacı ve Arıcı, 2012; Zhiping ve diğer. 2012).

ZÖS'ler; yapay zekâ, web ve bilişim teknolojilerini kullan sistemlerdir (Erümit ve diğer., 2019; Mahdi, Al-habbash \& Naser, 2016) Bu sayede bir öğreticinin davranışlarını model olarak öğrenenin bir sınıf ortamın-daymış gibi ilerlemesini destekleyerek ve anlık dönütler sağlayarak öğrenme sürecine rehberlik yapabilmektedir (Keleş \& Keleş, 2017). Sahip olduğu bu dönüt sistemi ile kullanıcılar sorulara verdikleri cevaplara göre aldıkları dönütlerle öğretim sürecinde ilerlerler (Murray ve Pérez, 2015). ZÖS sahip oldukları bu özelliklerle bir uzman sistem modelidir.

Uzman sistem belirli bir uzmanlık gerektiren alan ile ilgili çok geniş bir bilgiye sahip, o alandaki insan uz-manlarca sağlanan ve problem çözme sürecinde uzmanlar gibi davranış gösteren bilgisayar yazılımları olarak tanımlanmaktadır (Allahverdi, 2002; Keleş, Keleş ve Akçetin, 2017; Körez, 2009). Uzman sistemler doğası gereği, kullanıcıya bireyselleştirilmiş problemler ve dönütler sunabilmektedir. Uzman sisteme dayalı eğitim yazııımları, öğrencilerin eğitim süreci boyunca gelişimlerini ve seçimlerini kayıt altına alan öğrenci merkezli modellerdir (Bahçeçi ve Gürol,2010; Önder, 2003).

Uzman sistemler, öğrencilerin bireysel farklılıklarına göre yönlendirme yaparak kişisel öğrenme süreçlerini yapılandırırlar. ZÖs'ler ile öğretim sürecinde, öğrencilerin vermiş oldukları yanıtların doğru olup olmadığı, öğrencilerin sorulara yanıt verip vermedikleri, işlem çözüm adımlarını doğru yapıp yapmadıkları gibi durumları karşılaştırırlar. Bunun sonucunda elde ettikleri veriler ile öğrencilerin bireysel ihtiyaçlarına göre rehberlik yapar-lar. Sahip oldukları bu olanaklar sayesinde geleneksel öğretim yöntemlerine göre daha etkili bir öğrenme fırsatını daha az zamana ihtiyaç duyarak sağlayabilmektedir (Demir, 2015; Hotomaroğlu, 2002). Çünkü ZÖS modeline sahip yazııımlar öğrencilere öğretim sürecinde yaptıkları hatalara daha hızı açıklama ve dönüt sağ-layabilmektedir (Kaya ve Korkmaz, 2007). Bu dönüt sistemi öğretmene öğretim sürecinde zaman tasarrufu gibi birçok olanaklar sağlayabilmektedir (Demir, 2015). Bu sayede öğretmen ders sürecinde bireysel desteğe ihtiyaç duyan öğrencilerine daha fazla zaman ayırabilir. Ayrıca değerlendirme sürecinin temel ilkelerinden birisi değerlendirme stratejilerinin olabildiğince bireyselleştirilmiş olmasıdır (Turnbull ve diğer., 2007). ZÖS'ler sahip oldukları hızı ve bireyselleştirilmiş dönüt sistemi ile değerlendirme sürecinin daha etkin işe koşulmasını sağlayabilmektedir (Demir, 2015).

Değerlendirme, çoktan seçmeli testlerle genelde aynı kavrammış gibi düşünülse de, değerlendirme testi uygulamaktan, sonuçları puanlandırıp kaydetmekten çok daha fazlasını kapsayan bir süreçtir (Kargın, 2007). Değerlendirme, farklı ölçüm araçları ile elde edilen bilginin analizini ve bu analiz sonucunda elde edilen so-nuçların etkili ve uygun kararlarını içermelidir. Öğrencilerin değerlendirme sürecinde yapmış oldukları yanlışlar ve doğrular öğretim süreci için öğrencilerin mevcut durumları hakkında bazı önemli bilgiler sunabilmektedir. Bu bilgilerin başında da öğrencilerin sahip oldukları pozitif ve negatif bilgiler gelmektedir.

Pozitif bilgi "insanın ne yapacağını bilmesi" olarak tanımlanırken negatif bilgi ise "insanın ne yapacağını bilmemesi" olarak tanımlanmaktadır (Akpınar ve Akdoğan, 2010; Gartmeir ve diğer., 2008). Gartmeier ve di-ğer. (2008) ayrıca, negatif bilgiyi "hedefe gitmeyen yolları gösteren zihin uyarı işaretlerinin toplamı" olarak da tanımlanmaktadır. Bickhard (2004), rasyonel olarak kabul ettiği pozitif bilgiyi "hatalardan kaçınma" olarak tanımlamaktadır. Pozitif bilgi tek başına öğrenmede yeterli fırsatları sağlayamabilir (Akpınar ve Akdoğan, 2010). Bu nedenle iki bilginin birlikte etkin kullanınımı öğretim süreci için daha nitelikli dönüt imkanı sağlayabi-lir.

Üst düzey öğrenme ve bilgide derinlemesine uzmanlaşabilmek için pozitif bilgilere sahip olmak tek başına yeterli olmayabilir. Ayrıca, insanın yeni bilgiler öğrenmesinde pozitif bilgi tek başına motive etmede yeterli olmayabilir. Hâlihazırda bildiğimiz ve kullandığımız birçok bilginin, geçmişte yaşadığımız başarısızlık ve hata-lara dayalı olduğu bilinmektedir (Akpınar ve Akdoğan, 2010). Birey, mevcut bilgileriyle örtüşmeyen bir durum-la karşılaştığında, yeniden 
mevcut bilgileri düşünerek ya da beklemeye geçerek yeni olan bu durumu tanımak için daha çok motive olur. Bu nedenle eski düşünme sistemleri ve bir konu hakkındaki eski öğrenmelerin (pozitif bilgi), bireyin yeni fırsatları ve potansiyelleri görmesine engel olduğu ve bu durumda negatif bilgiye de gereksinim duyduğu söylenebilir (Parviainen ve Eriksson, 2006). Bu nedenle öğretim sürecinde sadece pozitif bilgiye odaklanmak bireyin sorumluluk alarak yeni yöntemler denemesine engel olabilir. Sadece pozi-tif bilgiye dayalı stratejinin bireyin yaratıcılık ve girişimcilik gibi özelliklerinin geliştirilmesine de yeterince kat-kısı olmayacaktır. Çünkü öğrenciler doğru yaptıkları zamanlardansa, eğer doğru yönlendirilebilirlerse, hata yaptıkları zaman daha fazla mevcut durumu sorgulamaya başlarlar (Karadağ, 2004). Bu nedenle eğitim öğre-tim sürecinde sadece, bilinen ve amaca giden yolların tekrarı ile yetinmemelidir. Öğrencilerin; girişimcilik, risk alma, üst düzey öğrenme gibi özelliklerini desteklemeye yönelik negatif bilgiyi kullanarak sorgulama yapabi-lecekleri öğrenme etkinliklerinede yer verilmelidir. Bunu sağlamak için öğretim sürecinde, öğrenciye tecrübe-lerinden yararlanma şansı verecek hatalara kontrollü olarak belirli oranda yer verilebilir (Akpınar ve Akdoğan, 2010). Tespiti yapılmamış ön bilgi ile ilgili sorunlar ve hatalar anlama güçlüklerine ve kavram karmaşasına yol açabilir. Çünkü; öğrenciler öğretim sürecinin başında sahip olmaları gereken ön bilgilere sahip olmayabilirler, ön bilgilere sahip olmalarına rağmen onları yeterince kullanamayabilirler, birbiriyle uyuşmayan veya hatalı ön bilgilere sahip olabilirler ya da içerikte yer alan bilgiyi kullanamayabilirler. Bu tür durumlarda bireyler okuduk-larını anlamada sorun yaraşayabilirler ve hatta okuduklarını anlayamayabilirler. Bu nedenle, öğrenciye ön bil-giler sonucunda oluşan hatalarını düzeltmesine ve pozitif bilgiye ulaşmasına yardımcı olacak ortamların sağlanması önemlidir.

Negatif bilginin kullanımında dikkat edilmesi gereken noktalardan birisi de, öğrenme sürecinde öğrenci tarafından yapılan hataların, öğrencinin daha fazla hata yapmasını önleyecek şekilde kullanılmasıdır. Eğer öğren-ciye hatanın kaynağı tam doğru bir şekilde sunulmazsa yeni yanlış öğrenmelere ve kavram yanılgılarına yol açabilir. Heinze (2005), bunu "hatayı üretici bir şekilde kullanmak" olarak tanımlamaktadır. Bunun için bireyin hataları konusundaki farkındalığının ve bilgi düzeyinin yükseltilmesi çok önemlidir. Bu kapsamda, okulların birer "öğrenen organizasyonlar" haline getirilebilmesi için, hata ve başarısızıklar, birer "geri bildirim ve düzelti-ci eylem" olarak kullanılmalıdır (Alpkan ve Doğan, 2008). Böylece öğrencinin negatif bilgiyi kullanarak öğre-tim sürecinden daha fazla yararlanması sağlanabilir. ZÖS sahip olduğu dönüt sisteminin belirlenen hedeflere ulaşmasında bilgisayar destekli öğretim (BDÖ) yazılımları sahip oldukları görsel ve işitsel zenginlikler ile kav-ram yanılgılarının ve yanlış öğrenmelerin düzeltilmesinde kolaylıklar sağlayabilir (Demir, 2015). Diğer disiplin-lerin öğretiminde olduğu gibi matematik öğretimi için BDÖ uygulamaları ve yazılımları sahip oldukları birçok farklı özellikle üstün fırsatlar sağlayabilir.

Matematik eğitiminin amacı diğer eğitimlerde olduğu gibi bütün öğrencilerin öğrenmesini en üst seviyede gerçekleştirmektir. Fakat öğrencilerde genellikle matematik dersininin zor olduğuna yönelik algıları ve tutum-lar bulunmaktadır (Dursun ve Dede, 2004; Güveli ve diğer., 2011). Soyut içerikler barındıran matematik der-sinde öğretmen tarafından kullanılan öğretim yöntem ve tekniği de önem taşımaktadır (Günhan, 2006). Çünkü ön-koşul oluş ilişkilerinin yüksek olması, matematikte ön bir konuda öğrenme zorluğu yaşayan bir öğrencinin onu takip eden konularda başarılı olmakta güçlük yaşamasına neden olabilmektedir. Bu nedenle de öğrenci merkezli uygulamalara yer verilmesi gerekmektedir. Yetkin (2003), matematikte kavrama düzeyini geliştirme-nin önemli fakat zor bir hedef olduğunu belirtmektedir. Ayrıca, öğrencilerin matematikteki öğrenme güçlükle-rini ve bu güçlüklerin kaynağını bilmek, onları gidermeye yönelik öğretim yöntemi tasarlamak için önemli bir adımdır (Yetkin,2003). Ortaokul seviyesinde öğrencilerin öğrenme sürecinde sorun yaşadığı konulardan birisi de kesirler yani rasyonel sayılardır.

Ortaokul öğrencilerinin matematik öğretiminde öğrendikleri ilk soyut kavramlardan birisi kesir yani rasyo-nel sayı kavramıdır. Rasyonel sayıların öğrenilmesinde ve öğretiminde karşılaşılan sorunlar birçok araştırma-nın konusu olmuştur. Bu konuda yapılan araştırmaların bazılarında, ilkokul ve ortaokul öğrencilerinin kesir tanımı ile ilgili sorularda, tanımlanmış kesirleri yazmada ve eş parçalara ayırmada zorlandıkları (Ubuz ve Ha-ser, 2001), kesirler konusunda her seviyede temel kavramları anlamada sorunlar yaşadıkları (Aksu, 1997), kesir konusunu problem çözümünde kullanırken hatalar yaptıkları (Başgün ve Ersoy, 2001) sonuçlarına ula-şılmıştır. Kesirlerin öğretiminde yaşanan güçlükler, ortak hatalar ve kavram yanılgıları ile ilgili Ardahan ve Er-soy (2002), Başgün ve Ersoy (2000), Toluk (2000), Haser ve Ubuz (2000), İşeri (1997), Post (1989), Malcolm (1987) ve Sweetland (1984) tarafından araştırmalar yapılmıştır. Öğrenciler tarafından yapılan hataların temelin-de matematik işlem bilgisi ve kavram bilgilerinin birbirini tamamlayacak biçimde öğrenilmemiş olması ve öğrencilerin problem çözme süreci ile ilgili gerekli bilgi ve becerilere yeterli düzeyde sahip olmamaları bulun-maktadır. Uygulanan başarı testlerinde öğrenciler tarafından yapılan ortak hataların analizi yapıldığında, öğ-rencilerin yanlış kurallar kullanma, dikkatsiz işlem yapma gibi eksiklikleri ve hataları olduğu görülmüştür (Er-soy ve Ardahan, 2003). Örneğin bu süreçte öğrenciler kesirlerin pay ve paydalarını farkı iki tam sayıymış gibi algılayabilmektedirler (Soylu ve Soylu, 2005 ; Şiap ve Duru, 2004). Soylu ve Soylu (2005), ilköğretim 5. sınıf öğrencileri ile gerçekleştirmiş oldukları araştırmada öğrencilerin en önemli öğrenme güçlüklerinin; kesirlerin 
pay ve paydalarını ayrı ayrı tam sayı gibi düşünüp işlem yapmaları, kesirler konusu ile ilgili daha önceden öğrenmiş oldukları kuralları daha sonraki kurallara aktaramamaları olduğu sonucuna ulaşmışlardır. Örneğin öğrencilerin toplama işleminin kuralını çarpma işleminde de kullanmaya çalışma ve sözel kesir problemlerini kavramlaştıramama gibi hatalara düşmektedirler. Kesirlerde toplama işlemi ile ilgili sorularda öğrencilerin büyük bir çoğunluğu, pay ve paydayı birbirinden bağımsız tam sayı gibi düşünerek toplama işlemini yapa-bilmektedirler.

Öğrencilerin matematik öğretiminde karşılaştıkları güçlükler; aritmetik ve geometri kavramları ile ve cebir konularını ilk öğrenme süreci ile daha da artabilmektedir. İlkokul düzeyinde doğal sayıların öğretiminden son-ra özellikle kesir öğretiminin başladığı dönemlerde; öğrencilerin öğrenmede, öğretmenlerin de öğretme süre-cinde yaşadıkları güçlükler hızla artabilmektedir. Bu güçlükler öğrencilerin matematikte akademik başarılarını ve duyuşsal gelişimlerini olumsuz yönde etkiliyebilmektedir. Belirtilen nedenlerden dolayı; ilkokulun ilk yılla-rından başlayarak öğrencilerin derslerde gelişmeleri sürekli takip edilmeli, onların bilişsel ve duyuşsal alanlar-da karşılaştıkları öğrenme güçlükleri ve sorunları giderilmeli ve durumlarını iyileştirecek önlemler alınmalıdır (Ersoy ve Erbaş, 2005).

Sonuç olarak; matematik öğretim programı matematiğin doğasından dolayı içerdiği soyut kavramlar ve tanımlar nedeniyle öğrenciler için öğrenilmesi ve anlaşılması zor gelebilmektedir. Ayrıca, matematiğin öğreti-minde kullanılan geleneksel öğretim yöntem ve tekniklerinin, öğrenci başarısını arttırmada yetersiz kalması da matematiğin öğrenilmesini daha da zor hale getirebilmektedir. Bu nedenle, matematik öğretim programının yaş, öğrenme düzeyi ve farklı çevre koşulları gibi etmenler dikkate alınarak daha somutlaştırılmalı ve uygula-yarak öğrenmeye fırsat verecek şekilde öğretim süreci tasarlanmalıdır (Dusun ve Dede, 2004).

\section{Araştırmanın Amacı}

Bu çalışmanın amacı; matematik öğretiminde yaşanan sorunlara çözüm olabilecek hatalardan öğrenmeye dayalı elektronik öğrenme sistemi geliştirerek, bu öğrenme sisteminin öğrencilerin akademik başarılarına etkisini belirlemektir. Bu kapsamda matematikte yer alan "Rasyonel Sayılar" konusunun öğretimi için bir uz-man sistem modeli önerilmiştir. Önerilen bu modelde, öğrenci değerlendirme sürecinde verilen problemi çö-zerken yaptığı hatalarda sunulan dönütlerle hem öğrenme eksikliklerini hem de konuyu daha iyi öğrenebilir. Öğrenciye ayrıca tüm soruları tamamladıktan sonra hatalı cevapladığı konu başlıkları verilerek öğrenme süreci ile ilgili sorumluluk ve karar alması sağlanabilir. Sonuç olarak araştırma sürecinde belirtilen amaçları gerçek-leştirmeye yönelik dönüt sistemine sahip değerlendirme yazııımının öğrenci akademik başarısına etkisi araştı-rılacaktır.

\section{Araştırmanın Problemi}

Araştırmanın belirtilen amacına yönelik olarak problem "Matematik rasyonel sayılar konusunun öğretimin-de hatalardan öğrenmeye dayalı uzman sistem değerlendirme yazılımı kullananımının öğrencilerinin akademik başarılarına etkisi var mıdır?" olarak belirlenmiştir. Problemin çözümüne yönelik aşağıda yer alan alt problem-ler belirlenmiştir.

a) Hatalardan öğrenmeye dayalı uzman sistem değerlendirme yazılımının kullanıldığı deney grubu öğrenci-leri ile geleneksel öğrenme yaklaşımının uygulandığı kontrol grubu öğrencilerinin öntest puanları arasında anlamlı bir farklılık var mıdır?

b) Hatalardan öğrenmeye dayalı uzman sistem değerlendirme yazılımının kullanıldığı deney grubu öğrencilerinin öntest ve sontest puanları arasında anlamlı bir farklıık var mıdır?

c) Geleneksel öğretim yöntemlerinin kullanıldığı kontrol grubu öğrencilerinin öntest ve sontest puanları arasında anlamlı bir farklııık var mıdır?

ç) Deney grubu öğrencileri ile kontrol grubu öğrencilerinin sontest puanları arasında anlamlı bir farklılık var midır?

d) Deney grubu öğrencilerinin akademik başarı düzeylerinde anlamlı bir fark var ise bu farkın ortaya çık-masında etkili olan etmen/etmenler nelerdir?

\section{Yöntem}

Araştırmada öntest sontest deney ve kontrol gruplu yarı deneysel desen modeli kullanılmıştır. Deneysel model, değişkenler arasındaki neden-sonuç ilişkilerini keşfetmek amacıyla kullanılan araştırma modelleri ola-rak tanımlanmaktadır (Büyüköztürk, 2010). Yarı deneysel modelinin amacı da deneysel modelle aynıdır. Arala-rındaki farklılık, yarı deneysel modelde, kontrol ve deney gruplarının rasgele değil de gerçekleştirilen ölçüm-lerle seçilmesidir (Ekiz, 2003; Karasar, 2006). Araştırma sürecinde ilk önce öntest uygulanarak çalışma grup-ları belirlenmiştir. 
Gerçekleştirilen öntest sonuçları incelenerek 4 sınıftan başarı puan ortalamaları birbirine en yakın olan puan ortalamaları arasında anlamlı farklılık bulunmayan iki sınıf seçilerek çalışma grupları belirlen-miştir. Öntest sonrasında belirlenen deney grubu öğrencileri matematik dersi öğretim sürecinin 4 haftalık 8 ders saatlik bölümünde bilgisayar laboratuvarında hazırlanan uzman eğitim sistemi kullandırılarak uygulama yapılmıştır.

Kontrol grubu öğrencilerinde ise geleneksel öğretim yöntemleri olan anlatım, soru-cevap, göste-rip yaptırma yöntemlerinin bulunduğu öğretmen merkezli yöntemler kullanılmıştır. Ayrıca EBA (Eğitim Bilişim Ağı) yer alan sunum ve içerikler de öğretmen yönetiminde kullanılmıştır. Kapsam geçerliliği matematik dersi alan öğretmenleri tarafından incelenerek uygun olduğu belirtilen bu yazılımda öğrencilerin hata ve işlem hata-ları belirlenip bu hatalara uygun dönütler kullanıcıya sunulmaktadır. Yazılım geliştirme sürecinde hem alanya-zın hem de uygulamanın gerçekleştirildiği okulda görev yapan öğretmenlerle yapılan ikili görüşmelerde öğ-rencilerin en çok pay ve payda arası bölme işlemlerinde, işlem önceliklerinde, parantez işlemlerinde ve ras-yonel sayılarda üs kullanımlarında hatalar yaptığı belirlenmiştir. Bu nedenle yazılım içeriği soru geliştirme ve hazırlanan soruların hata ihtimallerinin tespitinde ilgili öğretmenlerden destek alınmıştır. Her bir işlem hatası için ayrı bir dönüt ve bildirim tasarımı gerçekleştirilmiştir. Böylece araştırmanın amacı olan negatif bilgiye dayalı öğrenme ortamının oluşturulması amaçlanmıştır. Kontrol grubunda ise yazılım kullanma olanağı veril-memiş sadece sınıfta ders öğretmeni tarafından geleneksel öğretim etkinlikleri gerçekleştirilmiştir. 5. haftanın sonunda deney ve kontrol grubu öğrencilerin akademik başarı durumları sontest ile tespit edilmiştir.

\section{Çalışma Grubu}

Araştırmada, yarı deneysel araştırma modeli kullanılmıştır. Bu nedenle kontrol ve deney grubunun belirlenmesinde tesadüfi seçim yapılmamış ve araştırmanın bağımlı değişkeni olan akademik başarı düzeyleri bakımından grupların benzer özellik taşıması uygulanan öntest kontrol edilmiştir. Uygulama süreci önce-sinde 7. sınıfta öğrenimlerini sürdürmekte olan 4 sınıfın tamamında rasyonel sayılar konusunda başarı testi uygulanmıştır. Yapılan öntest başarı testi sonucunda 4 sınıfın başarı testi ortalamaları hesaplanmıştır. Daha sonra sınıfların başarı testi ortalamaları t testi ile karşılaştırılarak puanlar arasında anlamlı farklıık bulunma durumları incelenmiştir. Öntest sonuçlarına göre 4 sınıftan rasyonel sayılar başarı testi sonuçları arasında anlamlı farklılık bulunmayan 2 sınıf çalışma grubu olarak belirlenmiştir. Bu sınıflardan birisi rast-gele olarak deney diğeri ise kontrol grubu olarak atanmıştır. Uygulama Çanakkale Merkez ilçede ortaokul 7. sınıfta öğrenimlerini sürdürmekte olan 71 katılımcı ile gerçekleştirilmiştir. Öğrencilerin cinsiyete göre dağıımları (Tablo 1) incelendiğinde katılımcıların \%53.5'inin kız, \%46,5'inin ise erkek öğrencilerden oluştu-ğu görülmektedir.

Tablo 1. Cinsiyete Göre Katılımcıların Dağııımı

\begin{tabular}{ccc}
\hline Cinsiyet & f & $\%$ \\
\hline Kız & 38 & 53.5 \\
Erkek & 33 & 46.5 \\
Toplam & 71 & 100 \\
\hline
\end{tabular}

Aşağıda yer alan Tablo 2'de öğrencilerin evlerinde bilgisayar bulunma durumuna göre dağııımları görülmektedir.

Tablo 2. Evinde Bilgisayar Bulunma Durumuna Göre Katılımcıların Dağılımı

\begin{tabular}{ccc}
\hline Bilgisayar Bulunma Durumu & $\mathbf{f}$ & \% \\
\hline Evinde Var & 51 & 71.2 \\
Evinde Yok & 20 & 28.8 \\
Toplam & 71 & 100 \\
\hline
\end{tabular}

Tablo 2'ye göre öğrencilerin çoğunluğunun (\%71.2) evinde bilgisayar bulunmaktadır. Öğrencilerin evinde bilgisayar ve internet kullanma sıklı̆ıı incelendiği zaman (Tablo 3) öğrencilerin \%40.8'nin evinde her gün bilgisayar ve internet kullandığı görülmektedir. Hiç bilgisayar kullanmadığını belirtenlerin oranı ise \%12.7'dir. 
Tablo 3. Bilgisayar ve İnternet Kullanım Sıklığına Göre Katılımcıların Dağılımı

\begin{tabular}{ccc}
\hline Bilgisayar Kullanım Sıklı̆ı & $\mathbf{f}$ & \% \\
\hline Her Gün & 29 & 40.8 \\
Haftada 3-4 Gün & 17 & 23.9 \\
Haftada 1-2 Gün & 16 & 22.5 \\
Kullanmıyor & 9 & 12.7 \\
Toplam & 71 & 100.0 \\
\hline
\end{tabular}

Katılımcıların bilgisayar ve internet kullandıkları günlerde geçirdikleri süre incelendiğinde (Tablo 4) öğrencilerden 5-7 saat gibi yoğun bir zamanını bilgisayarda geçirenlerin oranı yaklaşık \%17'dir. Bilgisayar başında 1 saatten az zaman geçirenler ile bilgisayarda hiç zaman geçirmeyenlerin toplamı ise yaklaşık \%13'tür. Öğrencilerin bilgisayar kullanım amaçları incelendiği zaman (Tablo 5) öğrencilerin bilgisayarı en çok sosyal ağlara bağlanma (\%42.3) amacıyla kullandığı görülmektedir. Bu kullanım amacını, oyun/eğlence (\%25.4) ve ödev araştırması (\%18.3) takip etmektedir.

Tablo 4. Bilgisayarda Geçirdikleri Süreye Göre Katılımcıların Dağılımı

\begin{tabular}{ccc}
\hline Bilgisayarda Geçirilen Süre & $\mathbf{f}$ & $\mathbf{\%}$ \\
\hline 1 saatten az & 9 & 12.7 \\
$1-3$ saat & 20 & 28.2 \\
3-5 saat & 21 & 2.6 \\
5-7 saat & 12 & 16.9 \\
Kullanmıyor & 9 & 12.7 \\
Toplam & 71 & 100.0 \\
\hline
\end{tabular}

Tablo 5. Bilgisayar Kullanım Amaçlarına Göre Katılımcıların Dağıımı

\begin{tabular}{ccc}
\hline Amaç Türü & $\mathbf{f}$ & $\mathbf{\%}$ \\
\hline Oyun/Eğlence & 18 & 25.4 \\
Sosyal Ağlar & 30 & 42.3 \\
Ödev/Araştırma & 13 & 18.3 \\
Video & 1 & 1.4 \\
Toplam & 71 & 100.0 \\
\hline
\end{tabular}

\section{Veri Toplama Araçları}

Bu araştırmada veriler, MEB EBA (Eğitim Bilişim Ağı) tarafından hazırlanan 20 soruluk matematik başarı testi ile toplanmıştır. Başarı testi okulda matematik öğretmeni olarak görev yapmakta olan 4 öğretmen tarafından incelenmiş ve rasyonel sayılar konusu akademik başarı düzeyini ölçmek amacıyla geçerli bir ölçme aracı olduğu belirtilmiştir. Kesirler öğretimini desteklemek amacıyla konu içeriğinde belirtilen kazanımların sağlanması ve değerlendirilmesi amacıyla araştırmacılar tarafından Adobe Animate animasyon ve içerik geliştirme programında öğretim yazılımı geliştirilmiştir. Öğretim yazııımının ekran görüntüsü Şekil 1'de verilmiştir. 


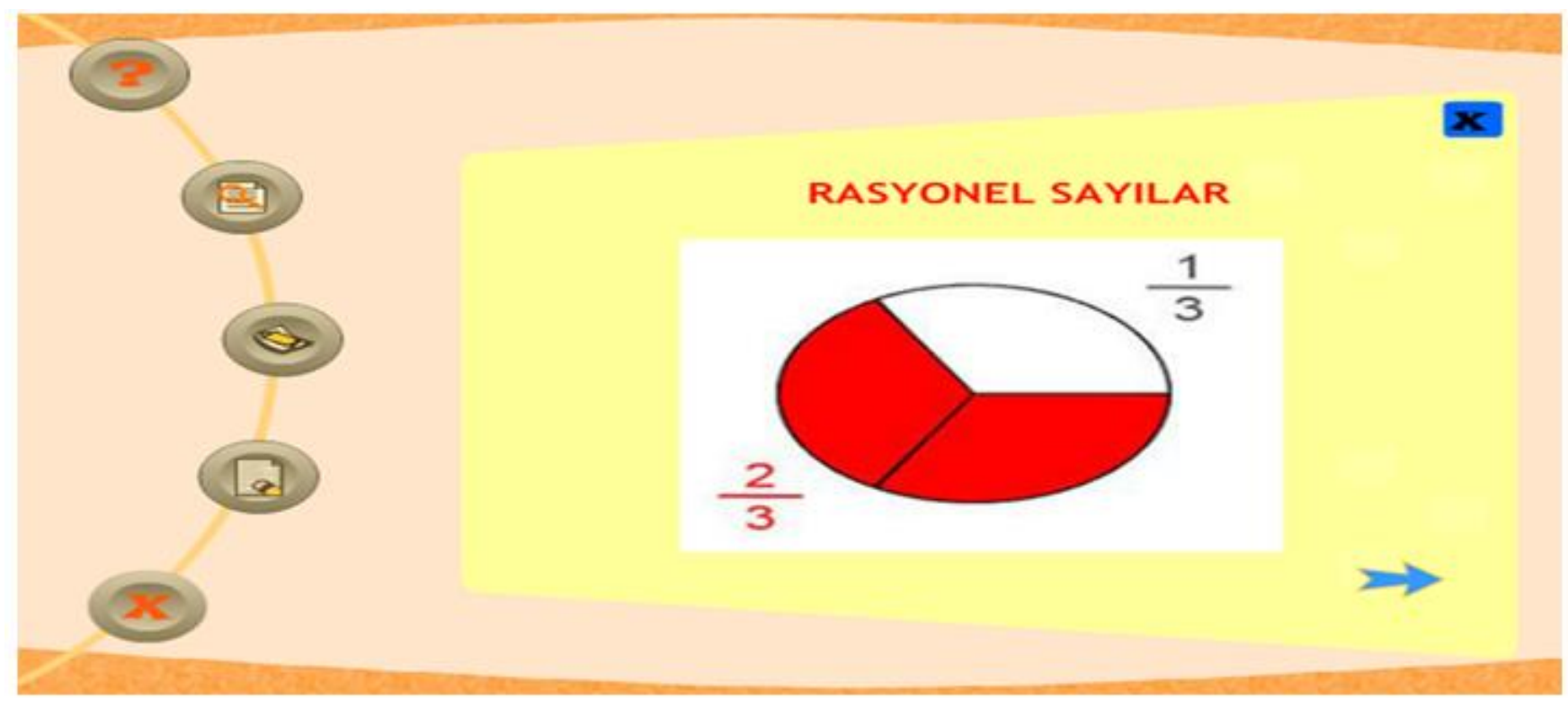

Şekil1. Öğretim Yazılımı Ekran Görüntüsü

Öğretim yazılımının içerik geliştirme sürecinde, hatasını saptamak ve hatasının kaynağını açıklayan yapıcı dönüt sistemiyle düzeltilmesine önem verilmiştir. Bu kapsamda, değerlendirme işlemlerinde çok seçenekli yanıtlardan birini öğrenciye seçtirmek yerine öğrencinin yanıtları kendisinin yazması sağlanmıştır. Bu tercih hatalardan öğrenme sisteminin doğasının gereğidir. Öğrenciye böylece hatalı veya doğru yanıt için hiçbir sınırlandırma veya yönlendirme yapılmamıştır.

Yazılımda kullanılan sorulara verilebilecek hatalı yanıtların tespitinde ve bu hatalara yönelik dönütlerin oluşturulmasında ilgili alan öğretmenlerinden yine destek alınmıştır.20 sorudan oluşan sorular ikiye bölünerek 10'arlı açık uçlu teste dönüştürülmüştür. İki sınıftan 52 öğrencinin katılımı ile gerçekleştirilen uygulama sonucunda öğrencilerin verdikleri yanlış yanıtlar incelenmiştir. Yazılım geliştirme sürecinde hem alanyazın hem de uygulamanın gerçekleştirildiği öğretmenlerin yapmış oldukları uygulama sonucunda öğrencilerin en çok pay ve payda arası bölme işlemlerinde, işlem önceliklerinde, parantez işlemlerinde ve rasyonel sayılarda üs kullanımlarında hatalar yaptığı belirlenmiştir. Bu nedenle yazııım içeriğinde belirlenen ilgili konulara ağırlık verilmiştir. Her bir işlem hatası için ayrı bir dönüt ve bildirim tasarımı gerçekleştirilmiştir. Böylece araştırmanın amacı olan negatif öğrenme ortamının oluşturulması amaçlanmıştır. Yazılım tasarımı tamamlandıktan sonra bilgisayar ve öğretim teknolojileri ve matematik alan öğretiminde ikişer akademisyenin uzman görüşüne başvurularak yazılımın geçerli ve kullanışlı bir yazııım olduğu bildirimi alınmıştır.

Hata bulma ve düzeltme sürecinde kullanıcıya sadece yanıtının doğru ya da yanlış olduğuna dair bilgilendirme yapılmamaktadır. Ayrıca yanıt verirken yaptığı hatanın nedeni ve doğru kullanımı hakkında da bilgi verilmektedir. Değerlendirme işlemlerine yönelik olarak hazırlanan dönüt tasarıma ilişkin örnek işlem ekran görüntüleri Şekil 2 ve Şekil 3'de verilmiştir. Şekil 2 ve 3 'de verilen matematik sorusunda bölme, çarpma ve işaret $(-,+)$ gibi hatalar yapılabilmektedir. Kodlama kısmında her bir hata durumu ayrı ayrı tanımlanarak işlem hatasında elde edilebilecek değerler ayrı ayrı tanımlanmıştır. Sonrasında her bir hatanın kaynağını düzeltecek dönüt tanımlamaları yapılmıştır. Şekil 2'de verilen soruda kullanıcı hatalı olarak +31/18 girmiştir. Kullanıının bu sonucu elde edilebilmesi için ilk parantezin yer aldığı işlem bölümünde bölme hatası yapmış olması gerekir. Parantez içerisindeki ikinci değerin (2/3) ters çevrilip ilk değer (1/3) ile çarpılması gerekmektedir. Fakat kullanıcı bu işlem hatasını yapınca 31/18 değerini elde etmektedir. Bu ekranda kullanıcıya bu hatası ile ilgili açıklama sunulmaktadır. Şekil 3'teki hata incelendiği zaman kullanıcı bölme hatası dışında ayrıca işaret (-) hatası da yapmıştır. Bu iki işlem hatası sonucunda 23/18 değerini elde etmektedir. Hata bulma ve düzeltme ekranında kullanıcıya yaptığı bu iki işlem hatasına yönelik dönüt sunulmaktadır. 


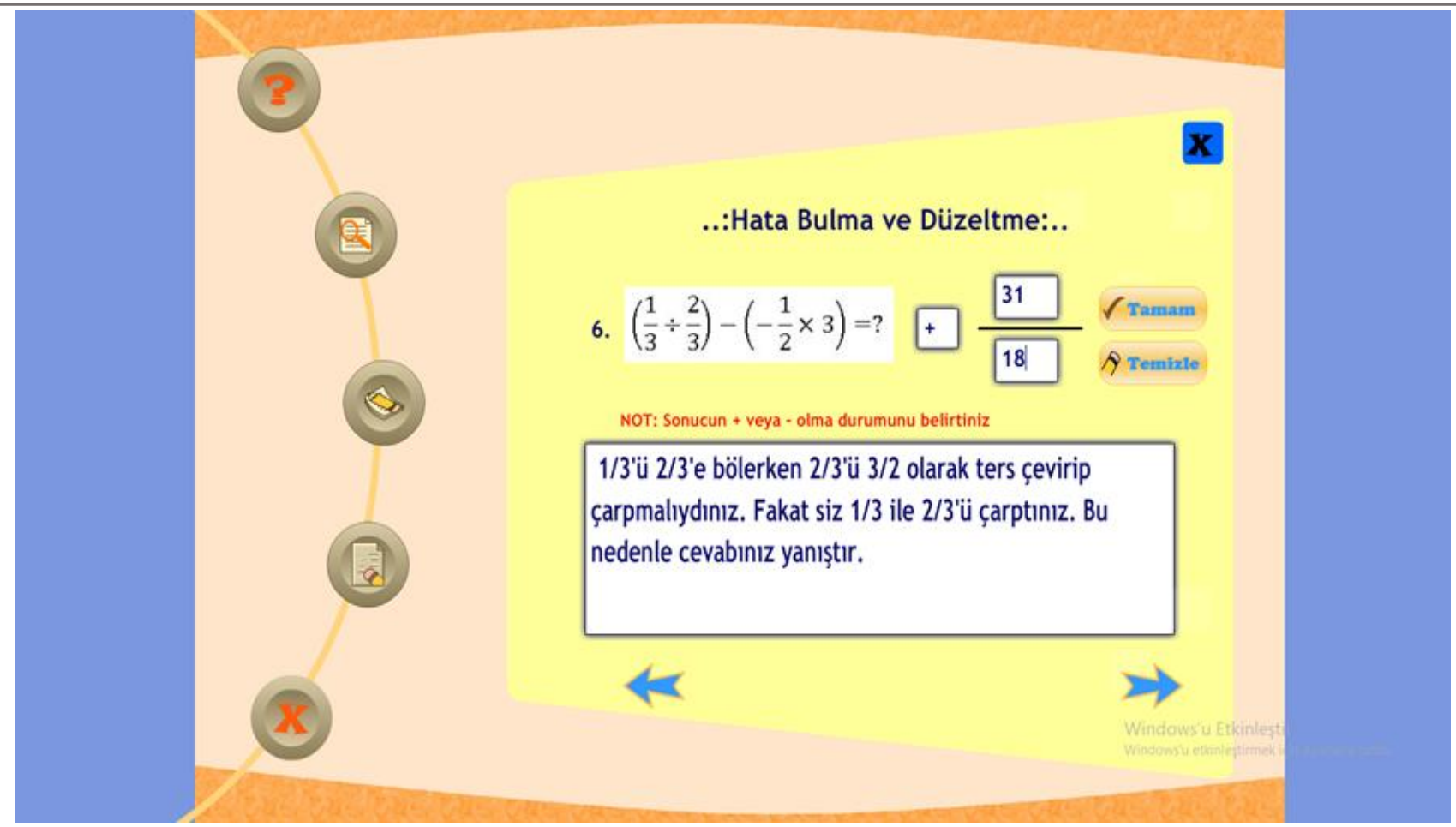

Şekil 2. Hata Bulma ve Düzeltme Ekran Görüntüsü

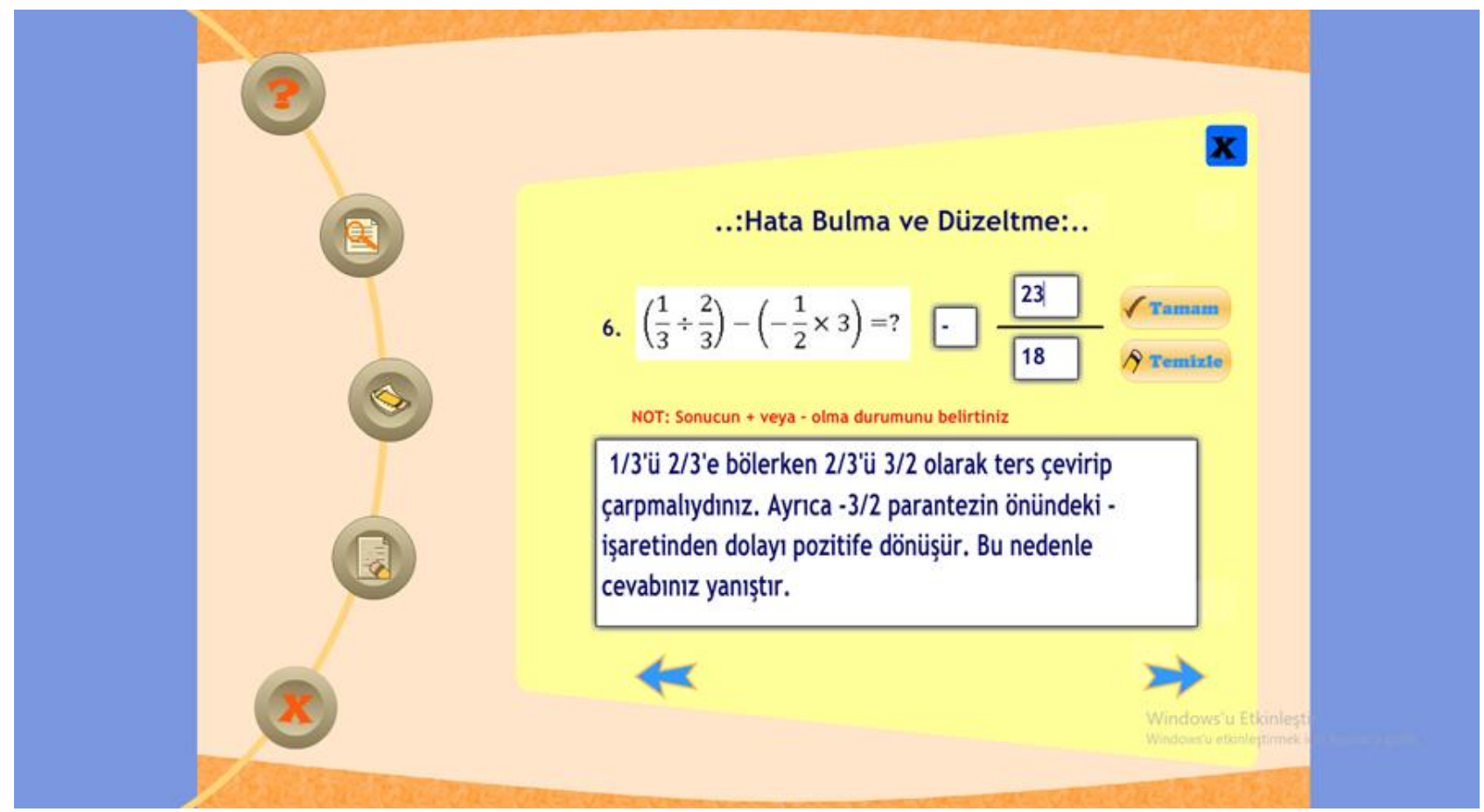

Şekil 3. Hata Bulma ve Düzeltme Ekran Görüntüsü

\section{Verilerin Analizi}

Araştırma sürecinde öğretmenler tarafından matematik akademik başarısı açısından benzer özellik taşıyan 2 farklı sınıfta öntestamacıyla başarı testi uygulanmıştır. Uygulanan başarı testi sonrasında belirlenen deney grubu öğrencileri matematik dersi öğretim sürecinin 4 haftalık 8 ders saatlik bölümünde bilgisayar laboratuvarında araştırmacılar tarafından geliştirilen hatalardan öğrenmeye dayalı uzman eğitim sistemi kullandırılak öğretimleri desteklenmiştir. Kontrol grubunda ise geleneksel öğretim yöntemleri kullanılarak sadece sınıfta öğretim etkinlikleri gerçekleştirilmiştir. 5. haftanın sonunda deney ve kontrol grubu öğrencilerin akademik başarı durumları sontest ile tespit edilmiştir. Araştırma sürecinde kullanılan öntest ve sontest ile kişisel bilgiler anketinden alınan veriler istatistik programı kullanılarak çözümlenmiştir. Literatürde alt grupların her birinin büyüklüklerinin 15 ve daha yüksek olması durumunda parametrik bir istatistiğin kullanılmasının, analizde hesaplanacak anlamlılık düzeyinde önemli bir sapmaya yol 
açmadığına ilişkin incelemeler buşunmaktadır (Büyüköztürk, 2010). Parametrik testler uygulanmadan önce, bu testlerin temel varsayımları sorgulanmıştır. Bu kapsamda öntest ve sontest sonuçlarının normal dağılım gösterip göstermediği Kolmogorov-Smirnov testi ile incelenmiştir. Hem öntest hem de sontest için $p>.05$ olduğu için parametrik analiz yöntemleri kullanılmıştır. Bu nedenle verilerin çözümlenmesinde aritmetik ortalama, standart sapma, $\mathrm{t}$-testi ve Anova testi kullanılmıştır.

\section{Bulgular}

\section{Alt Probleme Ait Bulgular}

Araştırmanın birinci alt problemi "Hatalardan öğrenmeye dayalı uzman sistem değerlendirme yazııımının kullanıldığı deney grubu öğrencileri ile geleneksel öğrenme yaklaşımının uygulandığı kontrol grubu öğrencilerinin öntest puanları arasında anlamlı bir farklılık var mıdır?" olarak belirlenmiştir. Kontrol ve deney grubu sonuçlarının normal dağııım kontrol ve deney gruplarında yer alan öğrencilerin öntest puanları arasında anlamlı bir farkın olup olmadığını belirlemek amacıyla gerçekleştirilen t testi (bağımsız gruplar için) analiz sonucu Tablo 6'da gösterilmiştir.

Tablo 6. Kontrol ve Deney Gruplarındaki Öğrencilerin Öntest Puanlarına ilişkin Bağımsız Gruplar için t-Testi Sonuçları

\begin{tabular}{ccccccc}
\hline Gruplar & $\mathbf{N}$ & $\overline{\mathbf{X}}$ & $\mathbf{s d}$ & $\mathbf{d f}$ & $\mathbf{t}$ & $\mathbf{p}$ \\
\hline Kontrol & 36 & 53.89 & 8.79 & 69 & -.82 & .42 \\
Deney & 35 & 56.14 & 13.9 & & & \\
\hline
\end{tabular}

Uygulanan öntest sonucunda kontrol ve deney grubu öğrencilerinin matematik dersi rasyonel sayılar konusundaki akademik başarı puanları arasında anlamlı bir farklılık olmadığı [t(69)=-0.82, p>.05] Tablo 6'da görülmektedir.

\section{Alt Probleme Ait Bulgular}

Araştırmanın ikinci alt problemi “Hatalardan öğrenmeye dayalı uzman sistem değerlendirme yazılımının kullanıldığı deney grubu öğrencilerinin öntest ve sontest puanları arasında anlamlı bir farklılık var mıdır?" şeklinde ifade edilmiştir. Deney grubunun öntest ve sontest puanları arasında anlamlı bir farkın olup olmadığını belirlemek amacıyla gerçekleştirilen t testi (Bağımlı Eşleştirilmiş Gruplar için) analiz sonucu Tablo 7'de gösterilmiştir.

Uygulanan sontest sonucunda deney grubu öğrencilerinin öntest ve sontest başarı puanları arasında anlamlı bir farklılık olduğu [t(34)=-7.85, $p<.05]$ Tablo 7 'de görülmektedir. Tablo verileri incelendiği zaman deney grubunun sontest puan ortalamasında önteste göre yaklaşık 9,5 puanlık bir artış görülmektedir.

Tablo 7. Deney Grubundaki Öğrencilerin Öntest-Sontest Puanlarına İlişkin Bağımlı Eşleştirilmiş Gruplar için t-Testi Sonuçları

\begin{tabular}{cccccccc}
\hline Gruplar & Test Türü & $\mathbf{N}$ & $\overline{\mathbf{X}}$ & $\mathbf{s d}$ & $\mathbf{d f}$ & $\mathbf{t}$ & $\mathbf{p}$ \\
\hline Deney & Öntest & 35 & 56.14 & 13.99 & 34 & -7.85 & $.00^{*}$ \\
& Sontest & 35 & 65.71 & 14.81 & & & \\
\hline
\end{tabular}

${ }^{*} \mathrm{p}<0.05$

\section{Alt Probleme Ait Bulgular}

Araştırmanın üçüncü alt problemi “Geleneksel öğretimin kullanıldığı kontrol grubu öğrencilerinin öntest ve sontest puanları arasında anlamlı bir farklııık var mıdır?" şeklinde ifade edilmiştir. Kontrol grubunun öntest ve sontest puanları arasında anlamlı bir farkın olup olmadığını ortaya koymak için t testi (ilişkilendirilmiş Bağımlı Gruplar için) analiz sonucu Tablo 8'de gösterilmiştir. Kontrol grubu öğrencilerinin öntest ve sontest başarı puanları arasında anlamlı bir farklıık olduğu [t(35)=-8.13, p<.05] Tablo $8^{\prime}$ de görülmektedir. Tabloda kontrol grubunun sontest başarı puan ortalamasında öntest puan ortalamasına göre yaklaşık 5,5 puanlık bir artış olduğu görülmektedir. Kontrol grubunun öntest-sontest başarı puanlarında gerçekleşen bu artış deney grubundaki artıştan daha düşük olmasına rağmen anlamlıdır.

Tablo 8. Kontrol Grubundaki Öğrencilerin Öntest-Sontest Puanlarına İlişkin iliş̧ilendirilmiş Bağımlı Gruplar için tTesti Sonuçları

\begin{tabular}{cccccccc}
\hline Gruplar & Test Türü & $\mathbf{N}$ & $\overline{\mathbf{X}}$ & $\mathbf{s d}$ & $\mathbf{d f}$ & $\mathbf{t}$ & $\mathbf{p}$ \\
\hline Kontrol & Öntest & 36 & 53.89 & 8.79 & 35 & -8.13 & $.00^{*}$ \\
& Sontest & 36 & 59.44 & 10.34 & & & \\
\hline
\end{tabular}

${ }^{*} \mathrm{p}<0.05$

\section{Alt Probleme Ait Bulgular}

Araştırmanın dördüncü alt problemi "Deney grubu öğrencileri ile kontrol grubu öğrencilerinin akademik başarı düzeyleri ile ilgili sontest puanları arasında anlamlı bir farklıık var mıdır?" şeklinde ifade edilmiştir. Deney ve kontrol 
gruplarının sontest puanları arasında anlamlı bir farkın olup olmadığını belirlemek amacıyla t testi (bağımsız gruplar için) analiz sonucu Tablo 9'da görülmektedir.

Uygulanan sontest sonucunda kontrol ve deney grubu öğrencilerinin başarı puanları arasında anlamlı bir farklılık olduğu [t(69)=-2.07, p<.05] Tablo 9'da görülmektedir. Tabloda deney grubunun sontest puan ortalamasının kontrol grubunun sontest puan ortalamasından yaklaşık 6 puan fazla olduğu görülmektedir.

Tablo 9. Deney ve Kontrol Gruplarındaki Öğrencilerin Sontest Puanlarına îlişkin Bağımsız Gruplar için t-Testi Sonuçları

\begin{tabular}{ccccccc}
\hline Gruplar & $\mathbf{N}$ & $\overline{\mathbf{X}}$ & $\mathbf{s d}$ & $\mathbf{d f}$ & $\mathbf{t}$ & $\mathbf{p}$ \\
\hline Kontrol & 36 & 59.44 & 10.34 & 69 & -2.07 & $.04^{*}$ \\
Deney & 35 & 65.71 & 14.81 & & & \\
\hline
\end{tabular}

${ }^{*} \mathrm{p}<0.05$

\section{Alt Probleme Ait Bulgular}

Araştırmanın beşinci alt problemi "Deney grubu öğrencilerinin akademik başarılarında anlamlı bir fark var ise bu farkın ortaya çıkmasında etkili olan etmen/etmenler nelerdir?” şeklinde ifade edilmiştir. Araştırma ölçeğinde yer alan bağımsız değişkenlerden; cinsiyete (öntest: $[\mathrm{t}(33)=.383, \mathrm{p}>.05]$, sontest : [t(33)=.732, p>.05]), bilgisayar kullanım süresine (öntest : $[F(3-27)=1.337, p>.05]$, sontest : $[F(3-27)=1.907, p>.05]$ ve kullanım sıklığına göre (öntest : [F(2$28)=1.17, p>.05]$, sontest : $[F(2-28)=.778, p>.05])$ başarı testi puanlarında anlamlı bir farklılık bulunamamıştır. Evinde bilgisayar kullanma olanağına göre başarı testi sonuçlarında ise anlamlı bir farklılık bulunmuştur.

Evinde bilgisayar kullanma olanağına göre deney grubu öğrencilerinin başarı puanlarına ilişkin Tablo 10 değerleri incelendiği zaman öğrencilerin öntest puanlarında anlamlı bir farklılık yok iken $[t(33)=1.11, p>$.05] uygulama sonrası gerçekleştirilen sontest puanlarında anlamlı bir farklılık olduğu [t(33)=2.19, p<.05] bulgusu elde edilmiştir. Buna göre evinde bilgisayar kullanma olanağının bulunması deney grubu öğrencilerinin matematik akademik başarılarını olumlu yönde etkilemiştir.

Tablo 10. Evinde Bilgisayar Kullanma Olanağına Göre Deney Grubu Öntest-Sontest Puanlarına i̇lişkin Bağımsız Gruplar için t-Testi Sonuçları

\begin{tabular}{cccccccc}
\hline Test Türü & Gruplar & $\mathbf{N}$ & $\overline{\mathbf{X}}$ & $\mathbf{s d}$ & $\mathbf{d f}$ & $\mathbf{t}$ & $\mathbf{p}$ \\
\hline Öntest & Bilgisayar Var & 25 & 57.80 & 14.22 & 33 & 1.11 & .27 \\
& Bilgisayar Yok & 10 & 52.00 & 13.17 & & 33 & .19 \\
Sontest & Bilgisayar Var & 25 & 69.00 & 13.54 & & & \\
& Bilgisayar Yok & 10 & 57.50 & 15.32 & & \\
\hline
\end{tabular}

${ }^{*} p<0.05$

\section{Sonuçlar}

Araştırmada elde edilen bulgular ışığında; uzman sistem değerlendirme yazılımı kullanan ve geleneksel öğretim alan öğrencilerin sontest puanları ile öntest puanları arasında anlamlı bir farklılık olduğu saptanmıştır. Ayrıca yazılımı kullanan deney grubu ile yazılımı kullanmayan kontrol grubunun öntest puanlarında anlamlı bir farklılık yok iken iki grup öğrencinin sontest puanları arasında anlamlı bir farklılık olduğu görülmüştür. Sonuç olarak hatalardan öğrenmeye dayalı uzman sistem değerlendirme yazılımı kullanımının öğrencilerin akademik başarılarında geleneksel öğretim yöntemi ile eğitim alan öğrencilere kıyasla daha fazla artış sağladığı görülmüştür. Araştırmada elde edilen bu sonuç zeki öğretim tabanlı uzman sistem yazılımı kullanımının öğrencilerin öğrenme hatalarının düzeltilmesinde etkili olduğunu belirten araştırma sonuçları ile örtüşmektedir (Ayas, Köse ve Taş, 2003: 106-112; Browning ve Lehmen, 1988: 741-761; Büyükkasap ve diğer., 1998: 59-66; Kaya ve Korkmaz, 2007; Mitrovic ve diğer., 2013; Woerner, 1980). Woerner (1980), gerçekleştirmiş olduğu araştırmada lise öğrencilerinin rasyonel sayılarda toplama işmi yaparken yaparken yaptıkları hataları tespit edip giderme işleminde bilgisayar teknolojisi araçlarını kullanmanın etkisini araştırmıştır. Çalışmada rasyonel sayılarda toplama işleminde yapılan hataların tespiti için uzman sisteme dayalı hata tespit sistemi geliştirilmiş ve bu sistemin etkililiği test edilmiştir. Bu kapsamda rasyonel sayıları toplamada öğrencilerin karşılaştıkları zorlukları yaptıkları hataları test etmek için BASıC programlama dilinde program geliştirilmiştir. Öğrenci cevaplarının analizinin yapıldığı bu uygulamada, öğrencilerin yaptıkları hatalar farklı kategorilere ayrılmıştır. Woerner (1980) bu çalışmasında, bilgisayarın lise öğrencilerinin rasyonel sayılarda toplama işleminde yaptıkları öğrenme hatalarının belirlenmesi ve giderilmesinde etkili bir şekilde kullanılabileceği sonucuna ulaşmıştır. Araştırma da elde edilen verilere göre geleneksel öğretim yöntemi de öğrencilerin akademik başarının 
artmasını sağlamıştır. Ayrıca deney grubunda da geleneksel öğretim yöntemi zeki öğretim sistemi yazılımı kullanımı ile desteklenmiştir. Bu nedenle geleneksel öğretim yöntemleri öğretim sürecinde etkili olduğu bu çalışma ile de ortaya çıkarılmıştır. Bu nedenle geleneksel öğretimi zenginleştirecek farklı öğretim materyallerinin ve teknolojilerinin kullanımına ağrlık verilmesinin öğretimin niteliğini arttıracağı düşünülmektedir.

Öğrenme sürecinde kalıcılı̆ın sağlanmasında kullanılan öğretim materyalinin birden fazla duyuya hitap etmesi oldukça önem taşımaktadır. Ayrıca, soyut ve öğrenciler için anlaşılması zor kavramlar öğretilirken öğrencilerin görsel ve düşünsel yapılarını motive ederek harekete geçirebilecek farklı ve ilgi çekici öğretim aktivitelerinin geliştirilip kullanııması oldukça önemlidir (Ertepınar ve diğer, 1998). Bu nedenle öğrenciyle etkileşim kuran öğretim sistemleri akademik olarak öğrenci gelişimlerini etkileyebilir.

Araştırmanın bağımsız değişkenleri olan cinsiyet, bilgisayar kullanım amacı, bilgisayar kullanım süresi ve bilgisayar kullanım sıklı̆̆ı ile öntest ve sontest akademik başarı testi arasında ilişki taramasında anlamlı bir farklılık bulunamamıştır. Evinde bilgisayar kullanma olanağına göre akademik başarı sonuçlarının anlamlı bir farklılık gösterdiği belirlenmiştir. Bu sonuç; Altuğ ve diğer. (2011), Baran ve Maskan (2012), Demir (2015), Olkun ve Altun (2003), Oral ve McGivney (2011) yaptığı araştırma sonuçları ile örtüşmektedir. Olkun ve Altun (2003), evinde bilgisayar kullanım olanağı bulunan öğrencilerin geometri akademik başarısında artış sağlanmıştır. Altuğ ve diğer. (2011), yapmış oldukları çalışmada bilgisayara sahip olmanın ortaöğretim öğrencilerinin akademik başarılarında olumlu etkiler yarattığını bulmuşlardır. Baran ve Maskan (2012), 11. Sınıf öğrencileri ile gerçekleştirmiş oldukları araştırmada akademik benlik tasarımı testi puan ortalamalarının evinde bilgisayar bulunma durumuna göre anlamlı farklılıklar gösterdiğini bulmuşlardır. Demir (2015), Türkçe öğretimine yönelik gerçekleştirdiği çalışmada evinde blgisayar bulunma durumunun akademik başarının artmasında etkili olduğu sonucuna ulaşmıştır. Oral ve McGivney (2011), hem fen bilimleri hem de matematik alanlarında başarılı olma duruları ile öğrencinin evinde bilgisayar ve internet olanağının bulunmasının doğrudan ilişkili olduğu sonucuna ulaşmışlardır. Yapılan bu araştırma alanyazında ulaşılan bu sonuçlar ile örtüşmektedir. Buna göre evde bilgisayar kullanım olanağııın bulunması akademik başarıda olumlu gelişmeler elde edilmesini kolaylaştırabilir.

Uzman sistem değerlendirme sistemi içeren öğretim yazılımı uygulamalarının, öğrencilerin hatalarının düzeltilmesini sağlayan dönüt sistemi içeren değerlendirme yapıları ile daha öğretici ve başarılı olabileceği düşünülmektedir. Çünkü yapılan hatalar sonucu elde edilen negatif bilginin dönüt sisteminde kullanımı öğretim süreci için farklı fırsatlar sağlayabilir. Bu fırsatlar; bireyin derinlemesine anlama seviyesine ulaşma, yeni farklı durumlarla baş edebilmeproblem çözme becerisini artırma, bilgide derinlemesine uzmanlaşmayı ve üst düzeyde öğrenmeyi destekleme seklinde olabilir (Akpınar ve Aydoğan, 2010). Ayrıca öğretim sürecinde sadece pozitif bilgiye odaklanılması, öğrencilerin risk alma, farklı yollar deneme, sorgulama ve farklı fırsatları görmekten alıkoyabilir. Bu durum ayrıca üst düzey öğrenme ve yaratıcılığı sınırlandırabilir. Ayrıca bireyler hata yaptıklarında ve başarısız olduklarında eğer çözüme ve doğru sonuca ulaşmak istiyorlarsa daha fazla sorgulamaya ihtiyaç duyabilirler. Zihinsel strese yol açan bu durum, derinlemesine öğrenme için önemli olanaklar oluşturabilir. Bu nedenden eğitimde, pozitif bilginin destekleyicisi olarak negatif bilgiye de yer verilmesinin birçok avantaj sağlayacağı düşünülmektedir. Ancak eğitimde hataların, bir öğrenme fırsatı ve yöntemi olarak kullanılırken, hataların daha çok hata yapmayı engelleyecek şekilde tasarlanması önemlidir. Heinze (2005), bu durumu "hatayı üretici bir şekilde kullanmak" olarak ifade etmektedir. Hataların etkin kullanımı ile birey, hatalardan daha etkili kaçınabilir.

\section{5. Öneriler}

Araştırmanın ortaya koyduğu bulgular ve elde edilen sonuçlara dayanarak aşağıda yer alan öneriler getirilmiştir:

a) Hatalardan öğrenmeye dayalı benzer çalışmaların daha uzun bir çalışma süresini kapsayacak biçimde ve daha geniş bir katıımcı katıımı ile gerçekleştirilip, sınanması ve başarı dışında tutum, hatırda tutma gibi boyutlar üzerindeki etkilerine bakılabilir.

b) Evde bilgisayar kullanım olanağının bulunmasının öğrencilerin akademik başarılarında olumlu etkiler meydana getirdiği sonucuna ulaşılmıştır. Mobil eğitimi esas alan hatalardan öğrenmeye dayalı uygulamalar ile uzaktan eğitime yönelik çalışmalar gerçekleştirilebilir.

c) Bu çalışma, matematik "Rasyonel Sayılar" öğretimi amacıyla gerçekleştirilmiştir. Bu nedenle diğer öğretim konularında ve farklı sınıf seviyelerinde ve branşlarda öğretimdeki etkililiği sınanabilir.

ç) Geleneksel öğretim yöntemi farklı öğretim teknolojilerle desteklenerek akademik başarıyı arttırmıştır. Bu nedenle geleneksel öğretimi geliştirecek ve etkinliği arttıracak çalışmalar gerçekleştirilebilir. 


\section{Kaynakça}

Akpınar, B., ve Akdoğan S. (2010). Negatif bilgi kavramı: hata ve başarısızlıklardan öğrenme. Batı Anadolu Eğitim Bilimleri Dergisi, 1(1), 14-22.

Allahverdi, N. (2002). Uzman Sistemler-Bir Yapay Zeka Uygulaması. İstanbul: Nobel Yayın Dağıtım.

Alpkan, L., ve Doğan, T. (2008). Stratejik planlama sureci bileşenlerinin firma performansına etkileri. Kocaeli Üniversitesi Sosyal Bilimler Enstitüsü Dergisi, 16(2), 21-47.

Altuğ, M., Gencer, C., ve Ersöz, F. (2011). Ortaöğretim öğrencilerinin hayatında bilgisayarın yeri. Bilişim Teknolojileri Dergisi, 4(1), 19-28.

Arıcı, N., ve Karacı, A. (2013). Türkçe öğrenimi için web tabanlı zeki öğretim sistemi (türkzös) ve değerlendirmesi. Turkish Studies, 8(8), 65-87.

Ayas, A., Köse, S., ve Taş, E. (2003). Bilgisayar destekli öğretimin kavram yanılgıları üzerine etkisi: fotosentez. Pamukkale Üniversitesi Eğitim Fakültesi Dergisi, 14(2), 106-112.

Bahçeci, F., ve Gürol, M.(2010). Eğitimde akıllı öğretim sistemleri uygulamalarına yönelik bir model önerisi. Engineering Sciences, 5(2), 121-128.

Baran, M., ve Maskan, A. (2011). Teknoloji ve proje destekli düşünme yolculuğunun öğrencilerin başarı ve akademik benlik tasarımlarına etkisinin evlerinde bilgisayar kullanımı durumu açısından incelenmesi. Amasya Üniversitesi Eğitim Fakültesi Dergisi, 1 (2), 115-127.

Bickhard, M. H. (2004). The Social Ontology of Persons. In J. I. M. Carpendale \& U. Muller (Eds.) Social interaction and the development of knowledge, 111-132, Psychology Press.

Browning, M.E., \& Lehmen, J.D. (1988). Identification of students' misconception in genetic problem solving via computer program. Journal of Research in Science Teaching, 25(9), 741-761.

Büyükkasap, E., Düzgün, B., Ertuğrul, M., ve Samancı, O. (1998). Bilgisayar destekli fen öğretiminin kavram yanılgıları üzerine etkisi. Kastamonu Ĕgitim Dergisi, 6, 59-66.

Büyüköztürk, Ş. (2010). Sosyal Bilimler İçin Veri Analizi El Kitabı. Ankara:Pegema Yayımcılık.

Dağ F., ve Erkan, K. (2004). Prolog tabanlı zeki öğretim sistemi. Pamukkale Mühendislik Bilimleri Dergisi. 10, 47-55.

Demir, Ü. (2015). Türkçe öğretiminde zeki öğretim sistemi eğitim yazııımı kullanımının öğrenci akademik başarısına etkisi. Ulus/ararası Eğitim Bilimleri Dergisi, (4), 480-496.

Dursun, Ş., ve Dede, Y. (2004). Öğrencilerin matematikte başarısını etkileyen faktörler matematik öğretmenlerinin görüşleri bakımından. Gazi Üniversitesi Gazi Eğitim Fakültesi Dergisi, 24(2), 217-230.

Ersoy, Y., ve Ardahan, H. (2003). Illköğretim Okullarında Kesirlerin Öğretimi II: Tanıya Yönelik Etkinlikler Düzenleme. Erişim: http://www. matder.org.tr/

Ersoy, Y., ve Erbaş, A. K. (2005). Kassel projesi cebir testinde bir grup Türk öğrencinin genel başarısı ve öğrenme güçlükleri. ilköğretim Online, 4(1), 18-39.

Ertepınar, H., Demircioğlu, H., Geban, Ö., ve Yavuz, D. (1998). Benzeşme ve bilgisayarlı öğretimin mol kavramını anlamaya etkisi, III. Ulusal Fen Bilimleri Eğitimi Sempozyumu, Karadeniz Teknik Üniversitesi, Trabzon.

Erümit, A. K., Çetin, I., Kokoç, M., Kösa, T., Nabiyev, V., \& Aygün, E. S. (2019). Designing a Usability Assessment Process for Adaptive Intelligent Tutoring Systems: A Case Study. Turkish Online Journal of Qualitative Inquiry, 10(1), .

Gartmeier, M., Bauer, J., Gruber, H., \& Heid, H. (2008). Negative knowledge: understanding professional learning and expertise. Vocations and Learning: Studies in Vocational and Professional Education, 1, 87-103.

Günhan, B. C. (2006). Ilköğretim II kademede matematik dersinde probleme dayalı öğrenmenin uygulanabilirliği üzerine bir araştırma (Doctora tezi, DEÜ Eğitim Bilimleri Enstitüsü).

Güveli, E., İpek, A. S., Atasoy, E., ve Güveli, H. (2011). Sınıf öğretmeni adaylarının matematik kavramına yönelik metafor algıları. Türk Bilgisayar ve Matematik Eğitimi Dergisi, 2(2), 140-159. 
Heinze, A. (2005). Mistake-Handling Activities in the Mathematics Classroom. International Group for the Psychology of Mathematics Education, 3, 105-112.

Hotomaroğlu, T. A. (2002). Bilgisayar Destekli Öğretim İçin Uzman Sistem Tabanlı Bir Kabuk Programın Geliştirilmesi ve Etkililiğinin Değerlendirilmesi. Yayınlanmış Doktora Tezi), Gazi Üniversitesi FBE, Ankara.

Karacı, A. (2014). Türkçede noktalama işaretleri ve büyük harf kullanımının öğretimi için zeki öğretim sistemi model önerisi. J Res Educ Teach, 15(3), 127-134.

Karacı, A., ve Arıcı, N. (2012). Zeki öğretim sistemleri için bilgisayar uyarlamalı test modülünün geliştirilmesi. Politeknik Dergisi, 15(3), 127-134.

Karadağ, Z. (2004). Hatalardan Öğrenme Yöntemi'nin Bilgisayar Destekli Matematik Öğretiminde Uygulanması (Koordinat Düzlemi ve Simetri Konusu). IETC 4. Uluslararası Eğitim Teknolojileri Konferansı, Sakarya

Kargın, T. (2007). Eğitsel değerlendirme ve bireyselleştirilmiş eğitim programı hazırlama süreci. Ankara Üniversitesi Eğitim Bilimleri Fakültesi Özel Eğitim Dergisi. 8(1), 1-13.

Kaya, S., ve Korkmaz, Ö. (2007). Zeki öğretim sistemi olarak tasarlanan exceltutor'un öğrenmeye etkisi. Ahi Evran Üniversitesi Kırşehir Eğitim Fakültesi Dergisi, 8(2), 171-187.

Keleş, A., \& Keleş, A. (2017). BiDEMAT-zeki öğretim sistemi. Electronic Turkish Studies, 12(6), 547-564.

Keleş, A., Keleş, A., \& Akçetin, E. (2017). Pazarlama alanında yapay zekâ kullanım potansiyeli ve akılı karar destek sistemleri. Electronic Turkish Studies, 12(11), 109-124.

Körez, A. (2009). Durum Tabanlı Öğrenci Modeli ile Zeki Öğretim Sistemi (ZÖS) Tasarımı. Yayımlanmamış yüksek lisans tezi, Marmara Üniversitesi, İstanbul.

Mahdi, A. O., Alhabbash, M. I., \& Naser, S. S. A. (2016). An intelligent tutoring system for teaching advanced topics in information security.World Wide Journal of Multidisciplinary Research and Development, 2(12), 1-9.

Mitrovic, A., Ohlsson, S., \& Barrow, D. K. (2013). The effect of positive feedback in a constraint-based intelligenttutoring system. Computers \& Education, 60(1), 264-272.

Murray, M. C., \& Pérez, J. (2015). Informing and performing : A study comparing adaptive learning to traditional learning. Informing Science: International Journal of an Emerging Transdiscipline, 18, 111-125.

Oral, I. ve Mcgivney, E. (2011). Türkiye'de Matematik ve Fen Bilimleri Alanlarında Öğrenci Performansı ve Başarının Belirleyicileri. Eğitim Reformu Girişimi TIMSS 2011 Analizi, İstanbul.

Olkun, S., ve Altun, A. (2003). İlköğretim öğrencilerinin bilgisayar deneyimleri ile uzamsal düşünme ve geometri başarıları arasındaki ilişki. The Turkish Online Journal of Educational Technology, 2(4), 86-91.

Önder, H. H. (2003). Uzaktan eğitimde bilgisayar kullanımı ve uzman sistemler. The Turkish Online Journal of Educational Techonology, 2(3), 142-146.

Parviainen, J., \& Eriksson, M. (2006). Negative knowledge, expertise and organisations. International Journal of Management Concepts and Philosophy, 2(2), 140-153.

Salvia, J., \& Ysseldyke, E.J. (2001). Assessment. (8th ed.). Boston: Houghton Mifflin.

Soylu, Y., ve Soylu, C. (2005). İlköğretim beşinci sınıf öğrencilerinin kesirler konusundaki öğrenme güçlükleri: kesirlerde sıralama, toplama, çıkarma, çarpma ve kesirlerle ilgili problemler. Erzincan Üniversitesi Eğitim Fakültesi Dergisi, 7(2), 101-117.

Şiap, İ., ve Duru, A. (2004). Kesirlerde geometriksel modelleri kullanabilme becerisi. Gazi Üniversitesi Kastamonu Eğitim Dergisi, 12(1), 89-96.

Troussas, C., Chrysafiadi, K., \& Virvou, M. (2019). An intelligent adaptive fuzzy-based inference system for computerassisted language learning. Expert Systems with Applications, 127, 85-96.

Tuna, G., ve Öztürk, A. (2015). Zeki ve uyarlanabilir e-öğrenme ortamları. In International Distance Education Conference (pp. 2-4).

Turnbull, A., Turnbull, R., \& Wehmeyer, M. L. (2007). Exceptional Lives: Special Education in Today's Schools. New Jersey: Prentice Hall. 
Woerner, K. L. W. (1980) Computer-based diagnosis and remediation of computational errors with fractions. Unpublished Doctoral Dissertation, The University of Texas, Austin.

Yetkin, E. (2003). Student Difficulties in Learning Elementary Mathematics. ERIC Digest.

Yıldırım, M. C., ve Dönmez, B. (2008). Yapılandırmacı öğrenme yaklaşımı uygulamalarının sınıf yönetimine etkileri üzerine bir çalışma. Illköğretim Online, 7(3), 664-679.

Zhiping, L., Yu, S., Tianwei, X., \& Yang, L. (2012). The Research Of Classical Learner Models in intelligent Tutoring Systems. Computer Science \& Education (ICCSE), 1204-1207. 